\title{
A study on awareness and behavior of women towards contraceptive use among women attending tertiary care center in northern Andhra Pradesh, India
}

\author{
Sridhar D. ${ }^{1}$, Swarnalatha M. ${ }^{2 *}$ \\ DOI: https://doi.org/10.17511/joog.2020.i03.02 \\ 1 Daneti Sridhar, Associate Professor, Department of Obstetrics and Gynaecology, Great Eastern Medical School and Hospital, Srikakulam, \\ Andhra Pradesh, India. \\ 2* Mandugavalasa Swarnalatha, Assistant Professor, Department of Obstetrics and Gynaecology, Great Eastern Medical School and Hospital, \\ Srikakulam, Andhra Pradesh, India.
}

Background: In spite of the constant efforts by the government, the unmet need for contraception (12.8\% in 2006 WHO report) is still there. There are many social factors, taboos, myths, and ignorance, which is responsible for the underutilization of contraceptive services. This leads to many unwanted pregnancies causing maternal morbidity and mortality. The aim of the study was to assess the knowledge, attitude, practices, and behaviour of women regarding various contraceptive methods. Material and Methods: It was a cross-sectional study of 1244 married women attending gynaecology OPD of Great Eastern Medical School and Hospital, Srikakulam, Andhra Pradesh (India). All participants were interviewed with a predesigned proforma. Results: Almost $88.5 \%$ of women were from a rural area and more than one-third were illiterate, belonging to low socioeconomic status. Awareness level about contraceptive methods was $92.3 \%$ among the participants and almost all of them knew about barriers and oral pills. The main source of knowledge was Healthcare Workers followed by media and social circles. Approximately $43.5 \%$ were currently using one or the other method of contraception. The barrier method was the most commonly used. The main reason for not using contraception was Desirous for Conception. Conclusion: There is a need to create awareness about the benefits of contraception.

Keywords: Contraception, Knowledge, Attitude, Behaviour, Andhra Pradesh

Corresponding Author

Mandugavalasa Swarnalatha, Assistant Professor, Department of Obstetrics and Gynaecology, Great Eastern Medical School and Hospital, Srikakulam, Andhra Pradesh, India.

Email: drswarnaobgy@gmail.com
How to Cite this Article

Sridhar D, Swarnalatha M. A study on awareness and behavior of women towards contraceptive use among women attending tertiary care center in northern Andhra Pradesh, India. Obs Gyne Review J Obstet Gynecol. 2020;6(3):67-71.

Available From

https://obstetrics.medresearch.in/index.php/joog/art To Browse

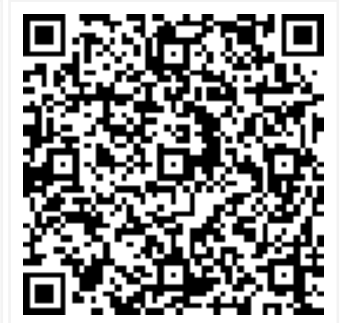
icle/view/111

Manuscript Received 2020-05-14

Conflict of Interest No
Review Round 1 2020-05-22

Funding Nil
Review Round 2 2020-05-28

Ethical Approval Yes
Review Round 3

Accepted 2020-06-04

Plagiarism X-checker $9 \%$

Note

(c) 2020 by Daneti Sridhar, Mandugavalasa Swarnalatha and Published by Siddharth Health Research and Social Welfare Society. This is an Open Access article licensed under a Creative Commons Attribution 4.0 International License https://creativecommons.org/licenses/by/4.0/ unported [CC BY 4.0]. 


\section{Introduction}

The fast-growing population is one of the main hazards to the development of India. India is the second-most populous country in the world and the rate of population growth is a matter of concern to the policymakers. even though India was one of the pioneers to start a family welfare program which started in the 1950s. [1,2,3]. In spite of the constant efforts by the government, the unmet need for contraception (12.8\% in 2006 WHO report) is still there $[4,5]$. There are many social factors, taboos, myths, and ignorance, which is responsible for the underutilization of contraceptive services. This leads to many unwanted pregnancies causing maternal morbidity and mortality. The use of effective contraception is one of the primary strategies to prevent maternal mortality and morbidity by decreasing unwanted pregnancies and abortions [6]. Understanding the contraceptive needs and practices of a particular community is essential to help policymakers design various policies. The present study was undertaken in patients attending gynaecology OPD for multiple reasons to know their attitude, behaviour, knowledge, and practice of contraceptive methods.

\section{Material and Methods}

The present study was a cross-sectional study undertaken on 1244 women attending gynaecology OPD at Great Eastern Medical school and Hospital, Srikakulam, Andhra Pradesh after obtaining IEC approval.

Duration and Type of Study: March 2017 to March 2018. Cross-sectional study.

Sample Size: One thousand two hundred forty-four married women interviewed with a set of predesigned questions.

Inclusion criteria: Married women in the age group of 20-45 years.

Exclusion Criteria: Women have any medical disorders which preclude the use of contraception, who were pregnant or lactating, infertile women excluded from the study.

Data Collection: After checking the inclusion criteria, the questionnaire mainly focused on contraceptive practices, socio-demographic data, age, parity, awareness regarding various contraceptive methods, current contraceptive use, and reason for not using any contraceptive method.
The results of the study expressed as a percentage.

Statistical analysis: The recorded data was compiled and entered in a spreadsheet computer program (Microsoft Excel 2007) and then exported to the data editor page of SPSS version 15 (SPSS Inc., Chicago, Illinois, USA). Descriptive statistics included computation of percentages, means, and standard deviations

\section{Results}

Table 1 shows the socio-demographic data of participants. The majority of the women were in the age group of $20-30$ years. $88.5 \%$ of women were from rural area and $70.8 \%$ had one living children. More than one-third of the women were illiterate. Most women had a single child at the time of the interview; this may be because the majority were in the adolescent age group of 20-30 years. Approximately $10 \%$ had a gap of fewer than two years between children.

Table-1: Baseline Data $(n=1244)$.

\begin{tabular}{|c|c|c|}
\hline Parameter & Number & Percentage (\%) \\
\hline \multicolumn{3}{|l|}{ Age (Years) } \\
\hline $20-30$ & 1047 & 84.16 \\
\hline $30-40$ & 197 & 15.8 \\
\hline \multicolumn{3}{|l|}{ Age of Husband } \\
\hline $20-30$ & 987 & 79.34 \\
\hline $30-40$ & 214 & 17.2 \\
\hline Above 40 & 41 & 3.2 \\
\hline \multicolumn{3}{|l|}{ Parity } \\
\hline $1-2$ & 1135 & 91.23 \\
\hline $3-4$ & 109 & 8.76 \\
\hline Above 4 & 0 & 0 \\
\hline Rural & 1101 & 88.51 \\
\hline Urban & 143 & 11.49 \\
\hline \multicolumn{3}{|l|}{ Educational Level } \\
\hline Illiterate & 491 & 39.46 \\
\hline Upto 10 STD & 301 & 24.19 \\
\hline Upto 12 STD & 205 & 16.47 \\
\hline Graduate and Above & 247 & 19.85 \\
\hline \multicolumn{3}{|c|}{ The gap between two children } \\
\hline 1 year & 43 & 3.45 \\
\hline $1-2$ years & 78 & 6.27 \\
\hline More than 2 years & 242 & 19.45 \\
\hline Having a single child & 881 & 70.81 \\
\hline \multicolumn{3}{|l|}{ BMI } \\
\hline Normal & 1052 & 84.56 \\
\hline Over-weight & 148 & 11.89 \\
\hline Under-weight & 44 & 3.53 \\
\hline
\end{tabular}


Most participants knew about at least 2 methods of contraception. The rest of the $7.7 \%$ were unaware of contraception. All of them who were aware knew about the barrier method, oral pills, and Sterilization. Only $7.8 \%$ had knowledge about CuT (Table 2).

Table-2: Knowledge and Awareness of Contraceptive Methods $(n=1244)$.

\begin{tabular}{|l|l|l|}
\hline \multicolumn{1}{|c|}{ Parameter } & Number & \multicolumn{1}{c|}{ Percentage (\%) } \\
\hline Aware & 1148 & 92.3 \\
\hline Unaware & 96 & 7.7 \\
\hline CuT & 98 & 7.8 \\
\hline Barrier & 1148 & 92.3 \\
\hline OCP & 1148 & 92.3 \\
\hline Sterilization & 1148 & 92.3 \\
\hline Safe period & 48 & 3.8 \\
\hline Injectables & 35 & 2.8 \\
\hline Coitus interruptus & 12 & 0.9 \\
\hline
\end{tabular}

The main source of knowledge was Healthcare Workers followed by Media and Social circles (Table 3).

Table-3: Source of Knowledge $(n=1148) . *$

\begin{tabular}{|l|l|l|}
\hline \multicolumn{1}{|c|}{ Source } & \multicolumn{1}{c|}{ Number } & \multicolumn{1}{c|}{ Percentage (\%) } \\
\hline Media & 386 & 33.6 \\
\hline Health worker & 647 & 56.6 \\
\hline Social circle & 115 & 10.1 \\
\hline Total & 1148 & 100 \\
\hline
\end{tabular}

*1148 women out of 1244 were aware of contraceptive methods

A total of $43.5 \%$ of participants were currently using contraception. The most commonly used method was barrier contraception (57.4\%).

More than one-fourth used oral pills and CuT use was quoted by $6.3 \%$. Other less commonly used methods were sterilization, safe period, and coitus interruptus. (Table 4)

The main reason for not using any contraceptive was Desirous for Conception (70.5\%).

A few were either worried about side effects or husband was either unwilling to use contraception or was staying away. (Table 4)

Table 4: Current Contraception being used ( $n=1244)$.

\begin{tabular}{|l|l|l|}
\hline \multicolumn{1}{|c|}{ Parameter } & \multicolumn{1}{c|}{ Number } & \multicolumn{1}{c|}{ Percentage (\%) } \\
\hline Users & 542 & 43.57 \\
\hline Non-users & 702 & 56.43 \\
\hline Total & 1244 & 100 \\
\hline
\end{tabular}

\begin{tabular}{|l|l|l|}
\hline Contraceptive method Used & 34 & 6.3 \\
\hline CuT & 311 & 57.4 \\
\hline Barrier & 165 & 30.4 \\
\hline OCP & 8 & 1.4 \\
\hline Stere period & 20 & 3.7 \\
\hline Coitus interruptus & 4 & 0.7 \\
\hline Total & 542 & 100 \\
\hline Reasons for non-use & \multicolumn{3}{|l|}{} \\
\hline Unaware & 96 & 13.7 \\
\hline Desirous for conception & 495 & 70.5 \\
\hline Worried about side effects & 27 & 3.8 \\
\hline Opposition from husband & 34 & 4.8 \\
\hline Inconvenience & 18 & 2.5 \\
\hline Husband staying away & 32 & 4.5 \\
\hline Total & 702 & 100 \\
\hline
\end{tabular}

A total of $43.5 \%$ of participants were currently using contraception. The most commonly used method was barrier contraception (57.4\%).

More than one-fourth used oral pills and CuT use quoted by $6.3 \%$. Other less commonly used methods were sterilization, safe period, and coitus interruptus (Table 4).

The main reason for not using any contraceptive was Desirous for Conception (70.5\%).

A few were worried about side effects, or the husband was either unwilling to use contraception or was staying away (Table 4).

\section{Discussion}

Rapidly increasing population is a cause of concern in India and a significant hazard to the development of the nation. Avoiding unwanted pregnancies is of utmost importance as unwanted pregnancies and related complications are a significant cause of maternal morbidity and mortality.

To achieve this goal, it is essential to have effective contraceptive use among the reproductive age couples. For using the right method of contraception, female literacy and knowledge are very important.

The present study showed that $92.3 \%$ of women were aware of one or the other method of contraception. Other studies have shown varying levels of awareness about contraceptive methods.

Awareness level was $87 \%$ in the study by Pegu B et al [7], and $100 \%$ in the study of Sunita TH et al [8] Awareness level was $87 \%$ in the study by Rao et al 
[9]. A significant source of knowledge was Healthcare Workers $(56.3 \%)$ followed by Media (33.6\%) and Social circle (10.1\%).

Similar results were shown in a study by Pegu B et al [7] showed health workers as the primary source of information about contraceptives followed by media and social circle. In a study by Sultan et al [10], media was the primary source of information.

In a study conducted in Ethiopia, almost in $80 \%$ of cases health workers were the primary source for disseminating knowledge about contraceptives [11] Gomal et al. showed friends/relatives as the primary source of information [12].

Only $43.5 \%$ of women were using one or the other method of contraception. $56.5 \%$ were not using any contraceptive. $62 \%$ of women in the study by Pegu et al. and $55 \%$ in the study by Srivastava et al. had never used any contraceptive method $[7,13]$.

$52 \%$ of participants in the study by Sunita TH et al. were not using any contraceptive, and when analyzed separately, contraceptive use was low among rural women compared to urban women [8]. Constant motivation by healthcare workers and increasing the awareness level is essential to improve contraceptive use among the population.

The post-partum period is the crucial time to highlight the need for contraceptive use as a patient is highly receptive at that point in time, and the need for contraception should highlight at each post-partum visit.

It is crucial to counsel both the partners as almost $4.8 \%$ of women quoted opposition from husband as a reason for not using any contraceptive, and none of the users quoted male sterilization as a contraceptive method.

A barrier was the most commonly used contraceptive method. A study by Pegu B et al. showed similar results. [7]. In contrast, Sunita $\mathrm{TH}$ et al. showed female sterilization as primary contraceptive use [8]. Though $92.3 \%$ were aware of contraception, still $43.5 \%$ were using contraception. This gap between knowledge and practice was seen in other studies as well.

To reduce this gap, the essential method is to have a free and full availability of family planning services and strong motivation by healthcare professionals. Couples should be offered with a range of contraceptive methods so that they can decide the one which suits them the most.

\section{Conclusion}

It is of utmost importance to increase the knowledge of women regarding various contraceptive methods, improving literacy rate, especially female literacy may of great help to achieve this goal. Besides this other barrier to contraceptive use like worry about side-effects, noncooperation by husband, needs to be addressed by strong motivation, education, and proper counseling. Improving the regular use of contraception will help to decrease maternal morbidity and mortality and will be of help for the development of the nation in a long way.

\section{What does the study add to the existing knowledge?}

The present study clearly shows that male sterilization is not seen as an option of contraception by many women. Hence, more studies to be done at the community level to create better programs thereby minimizing the factors which lead to the prevention of contraception.

\section{Author's contribution}

Dr. Mandugavalasa Swarnalatha formulated the aims and objectives with study design and helped in data collection and analysis. Dr. Daneti Sridhar contributed to the preparation of the questionnaire and manuscript.

\section{Reference}

01. Kaushal SK, Saxena SC, Srivastava VK, Gupta SC, Nigam S. KAP study on contraceptive methods in Kanpur district of UP. Ind $\mathrm{J}$ of Community Health. 2009;21(1)33-38.

[Crossref]

02. Govt Of India. Manual on decentralized participatory planning in Family Welfare Programme. Govt Of India. 1996, 1-3.

[Crossref]

03. Govt Of India. Ministry of Health and Family Welfare, Department Of Family Welfare. Manual on community needs assessment approach in the family welfare programme. 1998, 1-3. [Crossref]

04. WHO. Unmet need of contraception. WHO. 2013.

Available at:[Article] [Crossref] 
05. Hogmark S, Klingberg-Allvin $M$, GemzellDanielsson K, Ohlsson $H$, Essén B. Medical students' knowledge, attitudes and perceptions towards contraceptive use and counselling- a cross-sectional survey in Maharashtra, India. BMJ Open. 2013;3(12).

doi: [Article] [Crossref]

06. Collumbien M, Gerressu M, Cleland J. Non-use and use of ineffective methods of contraception, In- EzzatimM, Lopez AD, Rodgers AMurray CJL Eds Comparative quantification of health risksGlobal and regional burden of disease attributable to selected major risk factors. Geneva- World Health Organization. 2004;12551320.

Available at [Article] [Crossref]

07. Pegu B, Gaur BP Singh, Sharma N, Singh AS. Knowledge, attitude and practices of contraception among married women. Int J Reprod Contracept Obstet Gynecol. 2014;3(2)385-388.

doi: [Article] [Crossref]

08. Sunita TH, Desai RM. Knowledge, attitude and practice of contraception among women attending a tertiary care hospital in India. Int J Reprod Contracept Obstet Gynecol. 2013; 2(2)172-176.

doi: [Article] [Crossref]
09. Sultan K, Younus S. Mass media and family planning- understanding the effects of television in innovation decision process of health communication in district Peshawar. KUST Med J. $2010 ; 2(2) 58-63$.

[Crossref]

10. Senbeto E. A study on knowledge, attitude, practice and quality of care in family planning at Dessie Zuria District. J Ethiop Med Pract. 2001;3(2)70-76. doi: [Article] [Crossref]

11. Jabeen $M$, Gul $F$, Wazir $F$ and Javed $N$. Knowledge, attitude and practices of contraception in women of reproductive age. Gomal J Med Sci. 2011;9(2)223-229. [Crossref]

12. Srivastava $R$, Srivastava $D K$, Jina $R$, Srivastava K, Sharma N, Saha S. Contraceptive knowledge, attitude and practice (KAP Survey). J Obstet Gynaecol India. 2005;55(6)546-550.

[Crossref] 